COMMERCIAL PAPERS

\title{
Ghosts and guests
}

Authorship can be misused when there is money to be made. Medical journals contain a mixture of original scientific findings and veiled advertisements for drugs, and scientists and physicians must read papers critically to understand a medicine's true merits, says Alastair Matheson, a biomedical-research consultant in Toronto, Canada.

Some pharmaceutical companies make drugs and run clinical trials, then engage medical writers to draft manuscripts. These contributors are often ghostwriters not listed as authors on the paper. Instead, the company's marketing team finds a big academic name to headline the project - even if this guest author makes no contribution to the paper apart from scanning the final version. Companies sometimes use the same technique to produce reviews promoting their latest medicines, says Joseph Ross, a physician who studies health policy at Yale University in New Haven, Connecticut. One survey ${ }^{5}$ found that guests and ghosts haunted $21 \%$ of papers published in six leading medical journals in 2008.

"This vast production line of information about drugs is passed off as the work of academics rather than the work of industry," says Matheson. The companies get to advertise their products; the ghostwriters receive a pay cheque; and the academics get another line on their $\mathrm{CVs}$. But the patients and the integrity of science all lose out, says Matheson.

For example, Merck, a pharmaceutical company based in Whitehouse Station, New Jersey, minimized reporting of the risks observed for its painkiller Vioxx (rofecoxib) until the drug was taken off the market in 2004. Ross was a consultant to people who had taken Vioxx and developed heart problems, or their families, in two court cases against Merck, and he saw some of the company's internal documents ${ }^{6}$. "We were sort of shocked to find pretty rampant evidence that a lot of the trials were ghostwritten," says Ross. "We would stumble across a full draft of a manuscript that just said, 'external author?'."

There are ways to identify traces of guests and ghosts in a manuscript: "Check the small print," says Matheson. That is where a medical writer or communications company may be acknowledged. Funding from a drug-maker is another tell-tale sign. "These are pointers to the likelihood that this is something originated and planned by industry prior to the involvement of the headline authors," says Matheson. Author disclosures are less helpful, he adds, because academic authors may list several affiliations and it is difficult to tell which commercial relationship is relevant.

With commerce and medicine intimately intertwined, it would be impractical for academics to cut ties with companies, says Matheson. But, he adds, when academics are offered guest authorship, "I would advise them, for the sake of their reputation, to do two things". First, he says, be more than a guest: make sure that your contribution is author-level. Second, insist that company employees involved in the study are also listed as authors.

Matheson says it is the responsibility of journals to make participation by drugmakers more apparent. He would like to see papers marked right at the top with 'commercial article'. He also suggests that journals use labels to indicate who funded the study, and what drug it supports. A.D. became a 1,000-point system. The researchers who come up with the idea get 250 points, split between them according to their contribution; writing the paper is worth the same. A further 500 points are available for designing and running the experiment and analysing the data. Researchers who score at least 100 points make the author list, with each person's point total determining their rank.

Disagreements still occur; in those cases, Kosslyn decides how the points are allocated. When the balance of contributions is unclear, he does his best. However, it rarely comes to tallying points. "Usually it's very obvious what the order's going to be," he says.

In recent years, no disputes have ever risen to the level of the argument that led to the point system. "That," says Kosslyn, "was the last heated dispute we had in the lab." - SEE WORLD VIEW P.475

Amber Dance is a freelance science writer in Los Angeles, California.

1. Martinson, B. C., Anderson, M. S. \& de Vries, R. Nature 435, 737-738 (2005).

2. The ATLAS Collaboration J. Instrum. 3, S08003 (2008).

3. Maris, E. \& Check, E. Nature 439, 768-769 (2006).

4. The ENCODE Project Consortium Nature 489, 57-74 (2012).

5. Wislar, J. S., Flanagin, A., Fontanarosa, P. B. \& DeAngelis, C. D. Br. Med. J. 343, D6128 (2011)

6. Ross, J. S., Hill, K. P., Egilman, D. S. \& Krumholz, H. M. J. Am. Med. Assoc. 299, 1800-1812 (2008).

\section{POSTGRADUATES}

\section{Career-planning course}

The University of Pittsburgh in

Pennsylvania has launched a course on career planning for graduate students, one of the first to offer degree credits. Planning for Scientific Success aims to help students to identify and develop skills based on their interests and values, and to create a lifelong career-development plan. Steven Wendell, a molecular biologist and assistant director of the postdoctoral office at the university, proposed the course. "The career problems I hear from graduate students and postdocs are based in their lack of a clear, authentic career vision," he says. The course lasts for two semesters and is required for oral-biology graduate students at the University of Pittsburgh dental school, but is open to all graduate students at the university. Each semester is worth one credit.

\section{GRADUATES}

\section{Trouble with tracking}

Universities across Europe want to improve how they track graduates' career progression, says the European University Association (EUA) in Brussels. In Tracking Learners' and Graduates' Progression Paths, published on 13 September, the EUA finds that if institutions follow career outcomes, they can take steps to improve them, such as revising curricula or establishing strategies to improve communication skills. But of 23 institutions surveyed, $77 \%$ did not systematically track PhDholders' careers. Study co-author Michael Gaebel, head of higher-education policy at the EUA, says institutions should create a student database and team up to standardize data collection.

\section{CITATIONS}

\section{Nobel prizes predicted}

\section{On 19 September, Thomson Reuters} announced its annual 'citation laureates', whom it deems likely to win a Nobel prize. Since 2002, 26 of the predictions have come true. "We're trying to demonstrate that there is a strong correlation between citation at high frequency and peer esteem in science," says David Pendlebury, lead analyst for citation-laureate selection based in Eugene, Oregon. Each year, Reuters chooses up to nine candidates in each of the fields of chemistry, economics, physics and medicine. The 2012 laureates include researchers in genetic regulation, quantum teleportation and reducing the speed of light. 